\title{
Steroidogenic acute regulatory protein expression in the central nervous system
}

\author{
Steven R. King and Douglas M. Stocco* \\ Department of Cell Biology and Biochemistry, Texas Tech University Health Sciences Center, Lubbock, TX, USA
}

Edited by:

Hubert Vaudry, University of Rouen,

France

Reviewed by:

Gabriele M. Rune,

Universitätsklinikum Hamburg

Eppendorf, Germany

Synthia H. Mellon, University of

California San Francisco, USA

Charlier Dominique Thierry, University

of Liege, Belgium

${ }^{*}$ Correspondence:

Douglas M. Stocco, Department of

Cell Biology and Biochemistry, Texas

Tech University Health Sciences

Center, 3601 4th Street, Lubbock, TX

79430, USA.

e-mail:doug.stocco@ttuhsc.edu
Locally produced neurosteroids are proposed to have many functions in the central nervous system. The identification of the steroidogenic acute regulatory protein in steroid-producing neural cells provides a new tool to understand the sites, regulation, and importance of their synthesis.

Keywords: StAR, neurosteroid, P450scc, steroidogenic acute regulatory protein, STARD1, cholesterol, brain

\section{INTRODUCTION}

While the ovary, testes, and adrenal gland generate neuroactive steroids that impact brain function, the central nervous system (CNS) itself generates smaller levels of steroids (neurosteroids) de novo from cholesterol (Corpechot et al., 1983). The enzymes responsible for steroid synthesis localize to specific cell types within the CNS, including the two mitochondrial proteins that initiate steroidogenesis, cytochrome P450 side-chain cleavage (P450scc), and the steroidogenic acute regulatory protein (StAR/STARD1; Compagnone and Mellon, 2000; King et al., 2002).

Steroid hormone production begins with the conversion of cholesterol to pregnenolone by P450scc on the matrix side of the inner mitochondrial membrane (Bhangoo et al., 2006). Depending on the cell type, pregnenolone is further metabolized to other steroids, such as progesterone, allopregnanolone, and estrogen. The rate at which P450scc generates the steroid is determined by its access to cholesterol substrate. This access is controlled by StAR, which catalyzes the delivery of cholesterol from the outer mitochondrial membrane to the inner and P450scc (Figure 1; Clark et al., 1994).

Surprisingly, StAR elicits this intermembrane transfer from outside the mitochondria, prior to its import into the organelle, and processing to its mature $30-\mathrm{kDa}$ forms (reviewed in Bhangoo et al., 2006). This makes its difficult-to-detect $37-\mathrm{kDa}$ "precursor" the active form of StAR, solely due to its positioning outside the mitochondria. Import ends StAR activity. Thus, ongoing steroid synthesis requires ongoing synthesis of StAR.

In summary, the capability and capacity of a cell to make steroid is identified by the presence of P450scc. The rate and level of steroid production is marked by the expression level of StAR. Loss of either protein causes a catastrophic loss of circulating steroids (Hasegawa et al., 2000; Hu et al., 2002). While most research on StAR relates to its role in classic endocrine tissues in the gonads and adrenal gland, recent attention has turned to its importance in neurosteroid production in the CNS.

\section{EXPRESSION OF StAR IN THE ADULT AND DEVELOPING CNS}

The presence of StAR mRNA and protein in the CNS was first unambiguously demonstrated by Furukawa et al. (1998) and King et al. (2002) respectively. Subsequent research demonstrated the conservation of its presence in the brain evolutionarily, such as in the songbird and the eel (Li et al., 2003; London et al., 2006; London and Schlinger, 2007). Other data provide conflicting data for the expression and extent of expression of StAR in the fish brain and evidence for very low expression in the CNS of the stingray (Bauer et al., 2000; Kusakabe et al., 2002; von Hofsten et al., 2002; Nunez et al., 2005; Nunez and Evans, 2007).

Like P450scc and the enzyme that converts pregnenolone to progesterone, $3 \beta$-hydroxysteroid dehydrogenase $(3 \beta-\mathrm{HSD})$, the level of StAR in the brain is much lower than in endocrine tissues - approximately $0.1-1 \%$ of that found in the adrenal (Guennoun et al., 1995; Furukawa et al., 1998). However, StAR itself is expressed at a level much lower than $3 \beta-H S D$, but at least an order of magnitude greater than P450scc in the rat CNS (Mellon and Deschepper, 1993; Guennoun et al., 1995; Sanne and Krueger, 1995; Furukawa et al., 1998). Still, local concentrations of neurosteroids produced by neural cells can be far greater than that in serum.

Consistent with its critical role in steroidogenesis, StAR co-localizes with P450scc in the CNS (King et al., 2002). Steroidogenic regions marked by StAR and P450scc include 


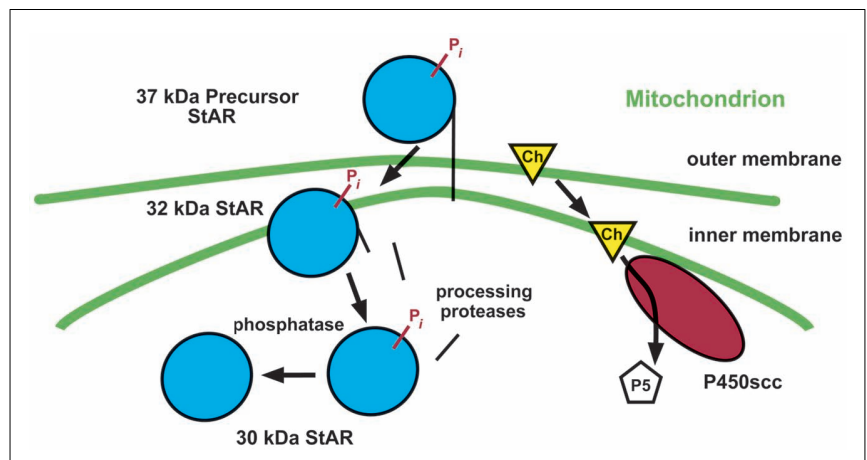

FIGURE 1 | Mechanism of StAR action. Following synthesis and an activating phosphorylation $\left(\mathrm{P}_{i}\right)$, StAR catalyzes the movement of cholesterol (Ch) in the outer mitochondrial membrane to the inner membrane through an unknown mechanism. There, cytochrome P450scc converts cholesterol to the steroid pregnenolone $\left(P_{5}\right)$, using reducing equivalents supplied by adrenodoxin reductase via adrenodoxin (not depicted). StAR is then imported into the mitochondria and processed to smaller forms.

the cortex, hippocampus, hypothalamus, cerebellum, and cranial nerve motoneurons (Compagnone et al., 1995; King et al., 2002; Sierra et al., 2003); summarized in (Do Rego et al., 2009). As with $\mathrm{P} 450 \mathrm{scc}$, StAR is expressed in specific neuronal and astrocyte populations. The two proteins co-localize to individual neuronal and glial cell types within the neonatal and adult brain (Mellon and Deschepper, 1993; Furukawa et al., 1998; King et al., 2002, 2004a). Specific cell types in the retina and Schwann cells synthesize both StAR and P450scc and hence, neurosteroids (Jung-Testas et al., 1989; Guarneri et al., 1994; Compagnone et al., 1995; Koenig et al., 1995; Patte-Mensah et al., 2003; Provost et al., 2003; Benmessahel et al., 2004).

The ability of the brain to synthesize neurosteroids is acquired early in development (Compagnone et al., 1995; Pezzi et al., 2003; King et al., 2004a). Embryogenesis marks the time of greatest neuronal growth and development as well as the peak of neurosteroid production. The developing CNS also expresses StAR in dividing cells and germinal layers (Sierra et al., 2003). Neonatal peaks in StAR, P450scc, and aromatase mRNA in Purkinje cells and other cerebellar neurons reflect high levels of de novo synthesis of progesterone and estradiol, which can regulate dendritic growth, spine, generation, and synaptogenesis (Sakamoto et al., 2003; Lavaque et al., 2006; Tsutsui, 2006). Developmental expression of StAR is also found in the zebra finch (London and Schlinger, 2007).

\section{REGULATION OF STAR EXPRESSION}

In endocrine tissues, trophic hormones like LH and ACTH control StAR expression and hence, steroid production. The identities of similar factors that regulate StAR in the CNS remain largely unknown.

In human SH-SY5Y neuroblastoma cells, gonadotropinreleasing hormone (GnRH) triples StAR and P450scc levels within 90 min via upregulation of LH (Rosati et al., 2011). As in gonadal tissues, levels of StAR in differentiated rat primary hippocampal neurons and human M17 neuroblastoma cells also respond to $\mathrm{LH}$ within $30 \mathrm{~min}$ (Liu et al., 2007). Whether these hormones influence StAR in vivo remains unclear, although $\mathrm{LH}$ and $\mathrm{GnRH}$ receptors have been identified, for instance, in hippocampal neurons (Lei et al., 1993; Webber et al., 2006; Wilson et al., 2006; Liu et al., 2007). Recent in vitro and in vivo studies also implicate a resident lipid, palmitoylethanolamide (PEA). PEA upregulates StAR and P450scc in the rat brain, rat C6 glioma cells, and murine astrocytes (Sasso et al., 2010; Raso et al., 2011).

The intracellular mechanism that governs StAR expression in neural tissue has been shown to involve the cAMP second messenger pathway as previously observed in endocrine tissues. Stimulation of the cAMP pathway induces StAR expression and steroidogenesis in neural cells (Papadopoulos and Guarneri, 1994; Roscetti et al., 1994; Arakane et al., 1997; Mellon et al., 2001; King et al., 2002; Jo et al., 2005; Lavaque et al., 2006; Manna et al., 2006; Karri et al., 2007). In one notable but unexplained exception, StAR mRNA levels decline with cAMP stimulation in Schwann cells in spite of increased neurosteroid production (Benmessahel et al., 2004). A preliminary report with an inflammatory model in mice indicates that StAR levels in the spinal cord as in testicular Leydig cells are derepressed with downregulation of COX-2, increasing analgesic neurosteroid production (Wang et al., 2003; Inceoglu et al., 2008). This effect on StAR may require increased cAMP.

\section{TRANSCRIPTION FACTORS CONTROLLING StAR EXPRESSION}

The trans-acting factors controlling StAR gene expression in the CNS remain elusive. The effect of PEA is mediated through its binding of the peroxisome-proliferator activated receptor (PPAR)$\alpha$ (Sasso et al., 2010; Raso et al., 2011). As in ovarian theca cells and mouse K28 Leydig cells, chronic stimulation with retinoic acid increases StAR and steroid production in GI-1 human glia cells (Kushida and Tamura, 2009; Lavoie and King, 2009). In contrast, long-term treatment with retinoid $\mathrm{X}$ and retinoic acid receptor ligand 9-cis-retinoic acid has no effect on StAR gene expression in rat hippocampal slices (Munetsuna et al., 2009b).

Interestingly, steroidogenic factor 1 (SF-1/NR5A1) and DAX1 which are critical in $S t A R$ gene regulation in endocrine tissues, appear to be mostly or entirely uninvolved. This is evidenced by the very limited number of regions expressing these transcription factors compared to StAR. Both SF-1 and DAX-1 localize to the rodent ventral medial hypothalamus (VMH; Guo et al., 1995; Ikeda et al., 1995, 1996; Shinoda et al., 1995b). In one report, SF-1 was identified in hippocampal neurons, with expression overlapping StAR and aromatase (Wehrenberg et al., 2001). Targeted knockout of the transcription factor disrupts the organization of the ventromedial nucleus (Shinoda et al., 1995a; Ikeda et al., 1996) and causes increased anxiety-like behavior (Kim et al., 2009). However, these changes are apparently unrelated to changes in neurosteroid production (Bhangoo et al., 2006; Kim et al., 2008).

An exciting aspect of neurosteroids is that certain neurosteroids such as allopregnanolone exert non-genomic changes primarily through ion channels found in target cells on the order of seconds to minutes. By implication, neurosteroids should be synthesized within a similar time frame. However, such rapid changes in de novo synthesis, while they may exist, have yet to be demonstrated. Such a change would likely involve translational or 
post-translational regulation of StAR, such as an activating phosphorylation of the protein by PKA (Roscetti et al., 1994; Arakane et al., 1997; Mellon et al., 2001; King et al., 2002; Jo et al., 2005; Lavaque et al., 2006; Manna et al., 2006). Increases within 5 min in steroid production have been observed in peripheral tissues, such as adrenocortical cells (DiBartolomeis and Jefcoate, 1984). It should be noted that other studies, primarily in birds, describe rapid (on the order of 5-10 min) changes in the levels of aromatase and $3 \beta$-HSD activities that result in modest alterations in the levels of neurosteroids metabolized from steroids obtained from peripheral sources (Balthazart et al., 2006; London et al., 2009).

\section{ROLE OF StAR IN THE BRAIN}

The multiplicity of regions expressing StAR and P450scc reflects the roles for a neurosteroids in a variety of CNS functions. By example, social isolation stress increases StAR expression in the hippocampus to elevate estrogen levels (Munetsuna et al., 2009a). Conflicting reports exist as to whether ethanol also increases StAR mRNA in the cortex and hippocampus (Serra et al., 2006; Boyd et al., 2010). The hypnotic effect of pentobarbital and antinociceptive activity at the level of the spinal cord are linked to PEAstimulated StAR-dependent allopregnanolone production in mice (Sasso et al., 2010, 2011). Increased production of StAR and neurosteroids in the spinal cord elicited by select anti-inflammatory factors are linked to antihyperalgesia (Inceoglu et al., 2008). Here, we summarize other studies that specifically describe the involvement of StAR.

\section{SEXUAL FUNCTION}

Neurosteroids and the proteins responsible for their synthesis like StAR and P450scc are found in structures relevant for sexual behavior and reproduction, such as the amygdala, medial preoptic area, and VMH (Compagnone et al., 1995; King et al., 2002; Sierra et al., 2003; King, 2008). The importance of neurosteroid production in reproduction is exemplified by the finding that inhibition of hypothalamic progesterone synthesis blocks the ovulatory $\mathrm{LH}$ surge in female rats (Micevych et al., 2003). The protein is also found in pituitary gonadotrope L $\beta$ T2 cells (Lopez de et al., 2007). StAR may serve a different function than in steroid production in these cells since they lack P450scc.

Differences in neurosteroids with gender are mirrored by differences in StAR. Male rats exhibit higher cerebellar levels of StAR, $\mathrm{P} 450 \mathrm{scc}$, and aromatase mRNAs and by implication, higher levels of neurosteroids (Lavaque et al., 2006). The opposite holds true for StAR in the zebra finch (Mirzatoni et al., 2010).

\section{NEUROPROTECTION}

Neurosteroids can be neuroprotective and their synthesis changes with aging and injury. Similarly, StAR changes with neuronal insults. For instance, excitotoxic stimuli like kainic acid and NMDA stimulate the generation of StAR and neurosteroids in the hippocampus (Kimoto et al., 2001; Sierra et al., 2003). Damage to the inferior olive elicited by i.p. injection of 3-acetylpyridine elevates StAR, P450scc, and aromatase mRNA levels in cerebellar neurons (Lavaque et al., 2006). The neuroprotective effects of PEA in murine astrocytes are linked to StAR-dependent allopregnanolone production (Raso et al., 2011).
Changes in neuroprotection and spinal density in hippocampal neurons correlate with StAR-dependent production of estrogen. Knockdown of StAR expression in these neurons reduces estradiol synthesis, increases cell death, reduces proliferation and causes alterations in spine densities, synaptic protein levels, and axon outgrowth in vitro (Fester et al., 2006; Prange-Kiel and Rune, 2006; Prange-Kiel et al., 2006; von Schassen et al., 2006). Given that GnRH can induce hippocampal estradiol synthesis, changes in spine density observed with the ovarian cycle may depend on changes in release of this hormone with the cycle within the hippocampus (Prange-Kiel et al., 2008, 2009).

Aging also increases StAR levels in the rat brain (Sierra et al., 2003). These changes may compose a neuroprotective response, mediated by neurons and astrocytes. Neurodegenerative diseases further evoke StAR expression. Levels of StAR rise in Alzheimer disease, notably in hippocampal pyramidal neurons that express LH receptors (Webber et al., 2006). This rise correlates with a similar increase in LH. In Niemann-Pick disease type C model mice, compromised expression of StAR and consequently, neuroprotective estradiol by affected cortical astrocytes relate to progression of the disease (Chen et al., 2007).

\section{StAR-INDEPENDENT STEROIDOGENESIS}

It is important to mention that StAR-independent pathways of intramitochondrial cholesterol transfer do exist, as exemplified in the human placenta, the only steroidogenic tissue known to not express StAR (Bhangoo et al., 2006). These pathways also reside in StAR-positive cell types, but generate fractional amounts of steroid compared to StAR. These pathways are largely uncharacterized, but contribute to basal steroid production and appear to be unregulated.

Unlike hydrophobic cholesterol, hydroxylated forms of cholesterol (oxysterols) can freely diffuse between mitochondrial membranes to P450scc without the assistance of StAR. Oxysteroldependent steroid production may be important in testicular development (Hutson, 2006). In the brain, the predominant oxysterol, 24S-hydroxycholesterol, could conceivably represent a source of neurosteroids (Lutjohann et al., 1996; King et al., 2004b).

A role for the peripheral-type mitochondrial benzodiazepine receptor/translocator protein (PBR/TSPO) alone or in coordination with StAR has also been proposed (Papadopoulos, 2004). Endozepines that bind PBR regulate de novo neurosteroid production in C6-2B glioma cells (Papadopoulos et al., 1992). Still, this ubiquitous protein usually exists in the outer mitochondrial membrane as part of the permeability transition pore complex, which controls mitochondrial integrity (Decaudin, 2004). In fact, PBR ligands can induce mitochondrial swelling and are pro-apoptotic (Chelli et al., 2001; Decaudin, 2004). Its knockout is embryonically lethal, reflecting an essential function beyond steroidogenesis, such as in apoptosis which also affects steroid production (Papadopoulos et al., 1997; King et al., 1998). Correspondingly, knockdown of PBR impairs mitochondrial protein import perhaps secondarily to loss of the electrochemical potential, also crucial to steroid synthesis (King and Stocco, 1996; King et al., 1999, 2000; Hauet et al., 2005). Therefore, while PBR may support carom steroid production, evidence for a direct role is lacking. 


\section{CONCLUSION}

Current research supports the presence of StAR as a measure of the level of neurosteroid production in the CNS and thus, a tool to probe the importance and regulation of neurosteroids. Factors that control StAR expression and activation control neurosteroid synthesis. The speed with which StAR and thus, neurosteroid synthesis occur represents a consideration in models of neurosteroid action.

Knockouts of StAR and P450scc should disrupt neurosteroid production in the brain and ergo, neurosteroid-regulated functions. Patients with mutations in these proteins present deficits in gonadal and adrenal steroids that manifest as congenital lipoid adrenal hyperplasia and non-classical familial glucocorticoid deficiency type 3 (Lin et al., 1995; Metherell et al., 2009; reviewed in King et al., 2011). The presentation of these conditions in patients and mouse models can include reproductive defects, hypoglycemia, and salt wasting. However, an increased incidence of cognitive deficits and brain developmental or behavioral

\section{REFERENCES}

Abdulhadi-Atwan, M., Jean, A., Chung, W. K., Meir, K., Ben, N. Z., Stratigopoulos, G., Oberfield, S. E., Fennoy, I., Hirsch, H. J., Bhangoo, A., Ten, S., Lerer, I., and Zangen, D. H. (2007). Role of a founder c.201_202delCT mutation and new phenotypic features of congenital lipoid adrenal hyperplasia in Palestinians. J. Clin. Endocrinol. Metab. 92, 4000-4008.

Arakane, F., King, S. R., Du, Y., Kallen, C. B., Walsh, L. P., Watari, H., Stocco, D. M., and Strauss, J. F. III. (1997). Phosphorylation of steroidogenic acute regulatory protein (StAR) modulates its steroidogenic activity. J. Biol. Chem. 272, 32656-32662.

Balthazart, J., Cornil, C. A., Taziaux, M., Charlier, T. D., Baillien, M., and Ball, G. F. (2006). Rapid changes in production and behavioral action of estrogens. Neuroscience $138,783-791$.

Bauer, M. P., Bridgham, J. T., Langenau, D. M., Johnson, A. L., and Goetz, F. W. (2000). Conservation of steroidogenic acute regulatory (StAR) protein structure and expression in vertebrates. Mol. Cell. Endocrinol. 168, 119-125.

Benmessahel, Y., Troadec, J. D., Cadepond, F., Guennoun, R., Hales, D. B., Schumacher, M., and Groyer, G. (2004). Downregulation of steroidogenic acute regulatory protein (StAR) gene expression by cyclic AMP in cultured Schwann cells. Glia 45, 213-228.

Bhangoo, A., Anhalt, H., Ten, S., and King, S. R. (2006). Phenotypic variations in lipoid congenital adrenal hyperplasia. Pediatr. Endocrinol. Rev. 3, 258-271.
Boyd, K. N., Kumar, S., O’Buckley, T. K., Porcu, P., and Morrow, A. L. (2010). Ethanol induction of steroidogenesis in rat adrenal and brain is dependent upon pituitary ACTH release and de novo adrenal StAR synthesis. J. Neurochem. 112, 784-796.

Chelli, B., Falleni, A., Salvetti, F., Gremigni, V., Lucacchini, A., and Martini, C. (2001). Peripheral-type benzodiazepine receptor ligands: mitochondrial permeability transition induction in rat cardiac tissue. Biochem. Pharmacol. 61, 695-705.

Chen, G., Li, H. M., Chen, Y. R., Gu, X. S., and Duan, S. (2007). Decreased estradiol release from astrocytes contributes to the neurodegeneration in a mouse model of Niemann-Pick disease type C. Glia

Clark, B. J., Wells, J., King, S. R., and Stocco, D. M. (1994). The purification, cloning, and expression of a novel luteinizing hormone-induced mitochondrial protein in MA-10 mouse Leydig tumor cells. Characterization of the steroidogenic acute regulatory protein (StAR). J. Biol. Chem. 269, 28314-28322.

Compagnone, N. A., Bulfone, A., Rubenstein, J. L., and Mellon, S. H. (1995). Expression of the steroidogenic enzyme P450scc in the central and peripheral nervous systems during rodent embryogenesis. Endocrinology 136, 2689-2696.

Compagnone, N. A., and Mellon, S. H. (2000). Neurosteroids: biosynthesis and function of these novel neuromodulators. Front. Neuroendocrinol. 21:1-56. doi:10.1006/frne.1999.0188

Corpechot, C., Synguelakis, M., Talha, S., Axelson, M., Sjovall, J., Vihko, R., Baulieu, E. E., and Robel, P. (1983). Pregnenolone and its sulfate ester 55, 1509-1518.

abnormalities separable from the physiologic phenotype has yet to be established (Bhangoo et al., 2006; Abdulhadi-Atwan et al., 2007). One possibility is that the brain adjusts to the permanent loss of neurosteroids during development. As well, changes in sexual behavior and function could be masked by the overriding effect of the loss of gonadal sex steroid production.

Still, these findings question the significance of neurosteroids. More rigorous and sophisticated studies of patients and knockout animals are required since many studies using inhibitors of steroidogenesis point to a vital role for these compounds in the CNS.

\section{ACKNOWLEDGMENTS}

The writing of this article was supported by NIH grant HD-17481 and with funds from the Robert A. Welch Foundation Grant B10028 (to Douglas M. Stocco) and NIH grant DK061548 (to Steven R. King).

in the rat brain. Brain Res. 270, 119-125.

Decaudin, D. (2004). Peripheral benzodiazepine receptor and its clinical targeting. Anticancer Drugs 15, 737-745.

DiBartolomeis, M. J., and Jefcoate, C. R. (1984). Characterization of the acute stimulation of steroidogenesis in primary bovine adrenal cortical cell cultures. J. Biol. Chem. 259, 10159-10167.

Do Rego, J. L., Seong, J. Y., Burel, D., Leprince, J., Luu-The, V., Tsutsui, K., Tonon, M. C., Pelletier, G., and Vaudry, H. (2009). Neurosteroid biosynthesis: enzymatic pathways and neuroendocrine regulation by neurotransmitters and neuropeptides. Front. Neuroendocrinol. 30:259-301. doi:10.1016/j.yfrne.2009.05.006

Fester, L., Ribeiro-Gouveia, V., PrangeKiel, J., von Schassen, C., Bottner, M., Jarry, H., and Rune, G. M. (2006). Proliferation and apoptosis of hippocampal granule cells require local oestrogen synthesis. J. Neurochem. 97, 1136-1144.

Furukawa, A., Miyatake, A., Ohnishi, T., and Ichikawa, Y. (1998). Steroidogenic acute regulatory protein (StAR) transcripts constitutively expressed in the adult rat central nervous system: colocalization of StAR, cytochrome P-450SCC (CYP XIA1), and 3betahydroxysteroid dehydrogenase in the rat brain. J. Neurochem. 71, 2231-2238.

Guarneri, P., Guarneri, R., Cascio, C., Pavasant, P., Piccoli, F., and Papadopoulos, V. (1994). Neurosteroidogenesis in rat retinas. J. Neurochem. 63, 86-96.

Guennoun, R., Fiddes, R. J., Gouezou, M., Lombes, M., and Baulieu, E. E.
(1995). A key enzyme in the biosynthesis of neurosteroids, 3 betahydroxysteroid dehydrogenase/delta 5-delta 4-isomerase ( 3 beta-HSD), is expressed in rat brain. Brain Res. Mol. Brain Res. 30, 287-300.

Guo, W. W., Burris, T. P., and McCabe, E. R. (1995). Expression of DAX-1, the gene responsible for $\mathrm{X}$-linked adrenal hypoplasia congenita and hypogonadotropic hypogonadism, in the hypothalamic-pituitaryadrenal/gonadal axis. Biochem. Mol. Med. 56, 8-13.

Hasegawa, T., Zhao, L., Caron, K. M., Majdic, G., Suzuki, T., Shizawa, S., Sasano, H., and Parker, K. L. (2000). Developmental roles of the steroidogenic acute regulatory protein (StAR) as revealed by StAR knockout mice. Mol. Endocrinol. 14, 1462-1471.

Hauet, T., Yao, Z. X., Bose, H. S., Wall, C. T., Han, Z., Li, W., Hales, D. B., Miller W. L., Culty, M., and Papadopoulos, V. (2005). Peripheral-type benzodiazepine receptor-mediated action of steroidogenic acute regulatory protein on cholesterol entry into leydig cell mitochondria. Mol. Endocrinol. 19, 540-554.

Hu, M. C., Hsu, N. C., El Hadj, N. B., Pai, C. I., Chu, H. P., Wang, C. K., and Chung, B. C. (2002). Steroid deficiency syndromes in mice with targeted disruption of Cyplla1. Mol. Endocrinol. 16, 1943-1950.

Hutson, J. C. (2006). Physiologic interactions between macrophages and Leydig cells. Exp. Biol. Med. (Maywood) 231, 1-7.

Ikeda, Y., Luo, X., Abbud, R., Nilson, J. H., and Parker, K. L. (1995). The nuclear receptor steroidogenic factor 1 is essential for the formation of the ventromedial hypothalamic nucleus. Mol. Endocrinol. 9, 478-486. 
Ikeda, Y., Swain, A., Weber, T. J., Hentges, K. E., Zanaria, E., Lalli, E., Tamai, K. T., Sassone-Corsi, P., Lovell-Badge, R., Camerino, G., and Parker, K. L. (1996). Steroidogenic factor 1 and Dax-1 colocalize in multiple cell lineages: potential links in endocrine development. Mol. Endocrinol. 10, 1261-1272.

Inceoglu, B., Jinks, S. L., Ulu, A., Hegedus, C. M., Georgi, K., Schmelzer, K. R., Wagner, K., Jones, P. D., Morisseau, C., and Hammock, B. D. (2008). Soluble epoxide hydrolase and epoxyeicosatrienoic acids modulate two distinct analgesic pathways. Proc. Natl. Acad. Sci. U.S.A. 105, 18901-18906.

Jo, Y., King, S. R., Khan, S. A., and Stocco, D. M. (2005). Involvement of protein kinase $\mathrm{C}$ and cyclic adenosine $\quad 3^{\prime}, 5^{\prime}$-monophosphatedependent kinase in steroidogenic acute regulatory protein expression and steroid biosynthesis in Leydig cells. Biol. Reprod. 73, 244-255.

Jung-Testas, I., Hu, Z. Y., Baulieu, E. E., and Robel, P. (1989). Neurosteroids: biosynthesis of pregnenolone and progesterone in primary cultures of rat glial cells. Endocrinology 125, 2083-2091.

Karri, S., Dertien, J. S., Stocco, D. M., and Syapin, P. J. (2007). Steroidogenic acute regulatory protein expression and pregnenolone synthesis in rat astrocyte cultures. J. Neuroendocrinol. 19, 860-869.

Kim, K. W., Jo, Y. H., Zhao, L., Stallings, N. R., Chua, S. C. Jr., and Parker, K. L. (2008). Steroidogenic factor 1 regulates expression of the cannabinoid receptor 1 in the ventromedial hypothalamic nucleus. Mol. Endocrinol. 22, 1950-1961.

Kim, K. W., Zhao, L., and Parker, K. L. (2009). Central nervous systemspecific knockout of steroidogenic factor 1. Mol. Cell. Endocrinol. 300, 132-136.

Kimoto, T., Tsurugizawa, T., Ohta, Y., Makino, J., Tamura, H., Hojo, Y., Takata, N., and Kawato, S. (2001). Neurosteroid synthesis by cytochrome p450-containing systems localized in the rat brain hippocampal neurons: N-methylD-aspartate and calcium-dependent synthesis. Endocrinology 142, 3578-3589.

King, S. R. (2008). Emerging roles for neurosteroids in sexual behavior and function. J. Androl. 29, 524-533.

King, S. R., Bhangoo, A., and Stocco, D. M. (2011). Functional and physiological consequences of StAR deficiency: role in lipoid congenital adrenal hyperplasia. Endocr. Dev. 20, 47-53.
King, S. R., Ginsberg, S. D., Ishii, T., Smith, R. G., Parker, K. L., and Lamb, D. J. (2004a). The steroidogenic acute regulatory protein is expressed in steroidogenic cells of the day-old brain. Endocrinology 145, 4775-4780.

King, S. R., Matassa, A. A., White, E. K., Walsh, L. P., Jo, Y., Rao, R. M., Stocco, D. M., and Reyland, M. E. (2004b). Oxysterols regulate expression of the steroidogenic acute regulatory protein. J. Mol. Endocrinol.32, 507-517.

King, S. R., Liu, Z., Soh, J., Eimerl, S., Orly, J., and Stocco, D. M. (1999). Effects of disruption of the mitochondrial electrochemical gradient on steroidogenesis and the Steroidogenic Acute Regulatory (StAR) protein. J. Steroid Biochem. Mol. Biol.69, 143-154.

King, S. R., Manna, P. R., Ishii, T., Syapin, P. J., Ginsberg, S. D., Wilson, K., Walsh, L. P., Parker, K. L., Stocco, D. M., Smith, R. G., and Lamb, D. J. (2002). An essential component in steroid synthesis, the steroidogenic acute regulatory protein, is expressed in discrete regions of the brain. $J$. Neurosci. 22, 10613-10620.

King, S. R., Rommerts, F. F., Ford, S. L., Hutson, J. C., Orly, J., and Stocco, D. M. (1998). Ethane dimethane sulfonate and NNN'N'-tetrakis(2-pyridylmethyl)ethylenediamine inhibit steroidogenic acute regulatory (StAR) protein expression in MA-10 Leydig cells and rat Sertoli cells. Endocr. Res. 24, 469-478.

King, S. R., and Stocco, D. M. (1996). ATP and a mitochondrial electrochemical gradient are required for functional activity of the steroidogenic acute regulatory (StAR) protein in isolated mitochondria. Endocr. Res. 22, 505-514.

King, S. R., Walsh, L. P., and Stocco, D. M. (2000). Nigericin inhibits accumulation of the steroidogenic acute regulatory protein but not steroidogenesis. Mol. Cell. Endocrinol. 166, 147-153.

Koenig, H. L., Schumacher, M., Ferzaz, B., Thi, A. N., Ressouches, A., Guennoun, R., Jung-Testas, I., Robel, P., Akwa, Y., and Baulieu, E. E. (1995). Progesterone synthesis and myelin formation by Schwann cells. Science 268, 1500-1503.

Kusakabe, M., Todo, T., McQuillan, H. J., Goetz, F. W., and Young, G. (2002). Characterization and expression of steroidogenic acute regulatory protein and MLN64 cDNAs in trout. Endocrinology 143, 2062-2070.

Kushida, A., and Tamura, H. (2009). Retinoic acids induce neurosteroid biosynthesis in human glial GI1 Cells via the induction of steroidogenic genes. J. Biochem. 146, 917-923.

Lavaque, E., Mayen, A., Azcoitia, I., Tena-Sempere, M., and GarciaSegura, L. M. (2006). Sex differences, developmental changes, response to injury and cAMP regulation of the mRNA levels of steroidogenic acute regulatory protein, cytochrome p450scc, and aromatase in the olivocerebellar system. J. Neurobiol. 66, 308-318.

Lavoie, H. A., and King, S. R. (2009). Transcriptional regulation of steroidogenic genes: STARD1, CYP11A1 and HSD3B. Exp. Biol. Med. (Maywood) 234, 880-907.

Lei, Z. M., Rao, C. V., Kornyei, J. L., Licht, P., and Hiatt, E. S. (1993). Novel expression of human chorionic gonadotropin/luteinizing hormone receptor gene in brain. Endocrinology 132, 2262-2270.

Li, Y. Y., Inoue, K., and Takei, Y. (2003). Steroidogenic acute regulatory protein in eels: cDNA cloning and effects of ACTH and seawater transfer on its mRNA expression. Zool. Sci. 20, 211-219.

Lin, D., Sugawara, T., Strauss, J. F., III, Clark, B. J., Stocco, D. M., Saenger, P., Rogol, A., and Miller, W. L. (1995). Role of steroidogenic acute regulatory protein in adrenal and gonadal steroidogenesis. Science 267, 1828-1831.

Liu, T., Wimalasena, J., Bowen, R. L., and Atwood, C. S. (2007). Luteinizing hormone receptor mediates neuronal pregnenolone production via up-regulation of steroidogenic acute regulatory protein expression. J. Neurochem. 100, 1329-1339.

London, S. E., Monks, D. A., Wade, J., and Schlinger, B. A. (2006). Widespread capacity for steroid synthesis in the avian brain and song system. Endocrinology 147, 5975-5987.

London, S. E., Remage-Healey, L., and Schlinger, B. A. (2009). Neurosteroid production in the songbird brain: a re-evaluation of core principles. Front. Neuroendocrinol. 30:302-314. doi:10.1016/j.yfrne.2009.05.001

London, S. E., and Schlinger, B. A. (2007). Steroidogenic enzymes along the ventricular proliferative zone in the developing songbird brain. J. Comp. Neurol. 502, 507-521.

Lopez de, M. R., Martin, B., Millar, R. P. Brown, P., Davidson, L., Pawson, A. J., Nicol, M. R., Mason, J. I., Barran, P., Naor, Z., and Maudsley, S. (2007). GnRH-mediated DAN production regulates the transcription of the $\mathrm{GnRH}$ receptor in gonadotrope cells. Neuromolecular Med. 9, 230-248.

Lutjohann, D., Breuer, O., Ahlborg, G., Nennesmo, I., Siden, A., Diczfalusy,
U., and Bjorkhem, I. (1996). Cholesterol homeostasis in human brain: evidence for an age-dependent flux of 24S-hydroxycholesterol from the brain into the circulation. Proc. Natl. Acad. Sci. U.S.A. 93, 9799-9804.

Manna, P. R., Chandrala, S. P., King, S. R., Jo, Y., Counis, R., Huhtaniemi, I. T., and Stocco, D. M. (2006). Molecular mechanisms of insulin-like growth factor-I mediated regulation of the steroidogenic acute regulatory protein in mouse leydig cells. Mol. Endocrinol. 20, 362-378.

Mellon, S. H., and Deschepper, C. F. (1993). Neurosteroid biosynthesis: genes for adrenal steroidogenic enzymes are expressed in the brain. Brain Res. 629, 283-292.

Mellon, S. H., Griffin, L. D., and Compagnone, N. A. (2001). Biosynthesis and action of neurosteroids. Brain Res. Brain Res. Rev. 37, 3-12.

Metherell, L. A., Naville, D., Halaby, G., Begeot, M., Huebner, A., Nurnberg, G., Nurnberg, P., Green, J., Tomlinson, J. W., Krone, N. P., Lin, L., Racine, M., Berney, D. M., Achermann, J. C., Arlt, W., and Clark, A. J. (2009). Nonclassic lipoid congenital adrenal hyperplasia masquerading as familial glucocorticoid deficiency. J. Clin. Endocrinol. Metab. 94, 3865-3871.

Micevych, P., Sinchak, K., Mills, R. H., Tao, L., LaPolt, P., and Lu, J. K. (2003). The luteinizing hormone surge is preceded by an estrogen-induced increase of hypothalamic progesterone in ovariectomized and adrenalectomized rats. Neuroendocrinology 78, 29-35.

Mirzatoni, A., Spence, R. D., Naranjo, K. C., Saldanha, C. J., and Schlinger, B. A. (2010). Injury-induced regulation of steroidogenic gene expression in the cerebellum. J. Neurotrauma 27, 1875-1882.

Munetsuna, E., Hattori, M., Komatsu, S. Sakimoto, Y., Ishida, A., Sakata, S., Hojo, Y., Kawato, S., and Yamazaki, T. (2009a). Social isolation stimulates hippocampal estradiol synthesis. Biochem. Biophys. Res. Commun. 379, 480-484.

Munetsuna, E., Hojo, Y., Hattori, M., Ishii, H., Kawato, S., Ishida, A., Kominami, S. A., and Yamazaki, T. (2009b). Retinoic acid stimulates 17beta-estradiol and testosterone synthesis in rat hippocampal slice cultures. Endocrinology 150, 4260-4269.

Nunez, B. S., and Evans, A. N. (2007). Hormonal regulation of the steroidogenic acute regulatory protein (StAR) in gonadal tissues of the Atlantic croaker (Micropogonias undulatus). Gen. Comp. Endocrinol. 150, 495-504. 
Nunez, B. S., Piermarini, P. M., Evans, A. N., and Applebaum, S. L. (2005). Cloning and characterization of cDNAs encoding steroidogenic acute regulatory protein from freshwater stingrays (Potamotrygon spp.). J. Mol. Endocrinol. 35, 557-569.

Papadopoulos, V. (2004). In search of the function of the peripheral-type benzodiazepine receptor. Endocr. Res. 30, 677-684.

Papadopoulos, V., Amri, H., Boujrad, N., Cascio, C., Culty, M., Garnier, M., Hardwick, M., Li, H., Vidic, B., Brown, A. S., Reversa, J. L., Bernassau, J. M., and Drieu, K. (1997). Peripheral benzodiazepine receptor in cholesterol transport and steroidogenesis. Steroids 62, 21-28.

Papadopoulos, V., and Guarneri, P. (1994). Regulation of C6 glioma cell steroidogenesis by adenosine 3',5'-cyclic monophosphate. Glia 10, 75-78.

Papadopoulos, V., Guarneri, P., Kreuger, K. E., Guidotti, A., and Costa, E. (1992). Pregnenolone biosynthesis in C6-2B glioma cell mitochondria: regulation by a mitochondrial diazepam binding inhibitor receptor. Proc. Natl. Acad. Sci. U.S.A. 89, 5113-5117.

Patte-Mensah, C., Kappes, V., FreundMercier, M. J., Tsutsui, K., and Mensah-Nyagan, A. G. (2003). Cellular distribution and bioactivity of the key steroidogenic enzyme, cytochrome P450side chain cleavage, in sensory neural pathways. $J$. Neurochem. 86, 1233-1246.

Pezzi, V., Mathis, J. M., Rainey, W. E., and Carr, B. R. (2003). Profiling transcript levels for steroidogenic enzymes in fetal tissues. J. Steroid Biochem. Mol. Biol. 87, 181-189.

Prange-Kiel, J., Fester, L., Zhou, L., Jarry, H., and Rune, G. M. (2009). Estrus cyclicity of spinogenesis: underlying mechanisms. J. Neural Transm. 116, 1417-1425.

Prange-Kiel, J., Fester, L., Zhou, L., Lauke, H., Carretero, J., and Rune, G. M. (2006). Inhibition of hippocampal estrogen synthesis causes regionspecific downregulation of synaptic protein expression in hippocampal neurons. Hippocampus 16, 464-471.

Prange-Kiel, J., Jarry, H., Schoen, M., Kohlmann, P., Lohse, C., Zhou, L., and Rune, G. M. (2008). Gonadotropin-releasing hormone regulates spine density via its regulatory role in hippocampal estrogen synthesis. J. Cell Biol. 180, 417-426.

Prange-Kiel, J., and Rune, G. M. (2006). Direct and indirect effects of estrogen on rat hippocampus. Neuroscience 138, 765-772.

Provost, A. C., Pequignot, M. O., Sainton, K. M., Gadin, S., Salle, S., Marchant, D., Hales, D. B., and Abitbol, M. (2003). Expression of SR$\mathrm{BI}$ receptor and StAR protein in rat ocular tissues. C. R. Biol. 326, 841-851.

Raso, G. M., Esposito, E., Vitiello, S., Iacono, A., Santoro, A., D’Agostino, G., Sasso, O., Russo, R., Piazza, P. V., Calignano, A., and Meli, R. (2011). Palmitoylethanolamide stimulation induces allopregnanolone synthesis in C6 cells and primary astrocytes: involvement of peroxisome-proliferator activated receptor-alpha. J. Neuroendocrinol. 23, 591-600.

Rosati, F., Sturli, N., Cungi, M. C., Morello, M., Villanelli, F., Bartolucci, G., Finocchi, C., Peri, A., Serio, M., and Danza, G. (2011). Gonadotropin-releasing hormone modulates cholesterol synthesis and steroidogenesis in SH-SY5Y cells. J. Steroid Biochem. Mol. Biol. 124, 77-83.

Roscetti, G., Ambrosio, C., Trabucchi, M., Massotti, M., and Barbaccia, M. L. (1994). Modulatory mechanisms of cyclic AMP-stimulated steroid content in rat brain cortex. Eur. J. Pharmacol. 269, 17-24.

Sakamoto, H., Mezaki, Y., Shikimi, H., Ukena, K., and Tsutsui, K. (2003). Dendritic growth and spine formation in response to estrogen in the developing Purkinje cell. Endocrinology 144, 4466-4477.

Sanne, J. L., and Krueger, K. E. (1995). Expression of cytochrome P450 side-chain cleavage enzyme and 3 beta-hydroxysteroid dehydrogenase in the rat central nervous system: a study by polymerase chain reaction and in situ hybridization. J. Neurochem. 65, 528-536.

Sasso, O., La, R. G., Vitiello, S., Russo, R., D’Agostino, G., Iacono, A., Russo, E., Citraro, R., Cuzzocrea, S., Piazza, P. V., De, S. G., Meli, R., and Calignano, A. (2010). Palmitoylethanolamide modulates pentobarbital-evoked hypnotic effect in mice: involvement of allopregnanolone biosynthesis.
Eur. Neuropsychopharmacol. 20, 195-206.

Sasso, O., Russo, R., Vitiello, S., Mattace, R. G., D’Agostino, G., Iacono, A., La, R. G., Vallee, M., Cuzzocrea, S., Piazza, P. V., Meli, R., and Calignano, A. (2011). Implication of allopregnanolone in the antinociceptive effect of N-palmitoylethanolamide in acute or persistent pain. Pain. doi: 10.1016/j.pain.2011.08.010

Serra, M., Mostallino, M. C., Talani, G. Pisu, M. G., Carta, M., Mura, M. L., Floris, I., Maciocco, E., Sanna, E., and Biggio, G. (2006). Social isolationinduced increase in alpha and delta subunit gene expression is associated with a greater efficacy of ethanol on steroidogenesis and GABA receptor function. J. Neurochem. 98 122-133.

Shinoda, K., Lei, H., Yoshii, H., Nomura M., Nagano, M., Shiba, H., Sasaki, H., Osawa, Y., Ninomiya, Y., Niwa, O., Morohashi, K.-I., and Li, E. (1995a). Developmental defects of the ventromedial hypothalamic nucleus and pituitary gonadotroph in the FtzF1 disrupted mice. Dev. Dyn. 204, 22-29.

Shinoda, K., Lei, H., Yoshii, H., Nomura, M., Nagano, M., Shiba, H., Sasaki, H., Osawa, Y., Ninomiya, Y., Niwa, O., Morohashi, K.-I., and Li, E. (1995b). Developmental defects of the ventromedial hypothalamic nucleus and pituitary gonadotroph in the FtzF1 disrupted mice. Dev. Dyn. 204 22-29.

Sierra, A., Lavaque, E., Perez-Martin, M. Azcoitia, I., Hales, D. B., and GarciaSegura, L. M. (2003). Steroidogenic acute regulatory protein in the rat brain: cellular distribution, developmental regulation and overexpression after injury. Eur. J. Neurosci. 18 , 1458-1467.

Tsutsui, K. (2006). Biosynthesis and organizing action of neurosteroids in the developing Purkinje cell. Cerebellum 5, 89-96.

von Hofsten, J., Karlsson, J., Jones, I., and Olsson, P. E. (2002). Expression and regulation of fushi tarazu factor-1 and steroidogenic genes during reproduction in Arctic char (Salvelinus alpinus). Biol. Reprod.67, 1297-1304.

von Schassen, C., Fester, L., Prange-Kiel, J., Lohse, C., Huber, C., Bottner, M., and Rune, G. M. (2006). Oestrogen synthesis in the hippocampus: role in axon outgrowth. J. Neuroendocrinol. 18, 847-856.

Wang, X., Dyson, M. T., Jo, Y., and Stocco, D. M. (2003). Inhibition of cyclooxygenase-2 activity enhances steroidogenesis and steroidogenic acute regulatory gene expression in MA-10 mouse Leydig cells. Endocrinology 144, 3368-3375.

Webber, K. M., Stocco, D. M., Casadesus, G., Bowen, R. L., Atwood, C. S., Previll, L. A., Harris, P. L., Zhu, X., Perry, G., and Smith, M. A. (2006). Steroidogenic acute regulatory protein (StAR): evidence of gonadotropin-induced steroidogenesis in Alzheimer disease. Mol. Neurodegener. 1,14 .

Wehrenberg, U., Prange-Kiel, J., and Rune, G. M. (2001). Steroidogenic factor-1 expression in marmoset and rat hippocampus: co-localization with StAR and aromatase. J. Neurochem. 76, 1879-1886.

Wilson, A. C., Salamat, M. S., Haasl, R. J., Roche, K. M., Karande, A., Meethal, S. V., Terasawa, E., Bowen, R. L., and Atwood, C. S. (2006). Human neurons express type I GnRH receptor and respond to $\mathrm{GnRH}$ I by increasing luteinizing hormone expression. J. Endocrinol. 191, 651-663.

Conflict of Interest Statement: The authors declare that the research was conducted in the absence of any commercial or financial relationships that could be construed as a potential conflict of interest.

Received: 27 July 2011; paper pending published: 02 September 2011; accepted: 24 October 2011; published online: 10 November 2011.

Citation: King SR and Stocco DM (2011) Steroidogenic acute regulatory protein expression in the central nervous system. Front. Endocrin. 2:72. doi: 10.3389/fendo.2011.00072

This article was submitted to Frontiers in Neuroendocrine Science, a specialty of Frontiers in Endocrinology.

Copyright (C) 2011 King and Stocco. This is an open-access article subject to a nonexclusive license between the authors and Frontiers Media SA, which permits use, distribution and reproduction in other forums, provided the original authors and source are credited and other Frontiers conditions are complied with. 